\title{
Estimating the growth of 20- to 26-year-old lodgepole pine plantations in the Leningrad region of Russia
}

\author{
Anatoly V. Zhigunov ${ }^{1} \bowtie$, Olesia Y. Butenko ${ }^{2}$ \\ ${ }^{1}$ Saint-Petersburg State Forest Technical University named after S.M. Kirov, Institutsky per. 5, 194021, St. Petersburg, \\ Russian Federation, e-mail: a.zhigunov@bk.ru \\ ${ }^{2}$ Saint-Petersburg Forestry Research Institute, Institutsky pr. 21, 194021, St. Petersburg, Russian Federation
}

\section{Abstract}

The aim of our study was to compare the growth rates of lodgepole pine (Pinus contorta Dougl.) with those of Scots pine (Pinus sylvestris L.) and Norway spruce (Picea abies L.) in plantations. The experimental plots were established in 1988, 1989 and 1994 in the southern part of the Leningrad region. In 2014, the condition of the plants on those plots was examined and their linear parameters were measured. The comparison of Scots pine with lodgepole pine of the same age growing in similar soil conditions has shown that Scots pine has only an insignificant advantage over lodgepole pine in the growth rate. In the mixes of Norway spruce and lodgepole pine, Norway spruce considerably suppresses the growth of lodgepole pine.

Lodgepole pine has successfully adapted to the climatic conditions of the Leningrad region of Russia, which is easy to see from the well-preserved plantations and their annual bearing. No significant damage because of either diseases or insect pests has been revealed.

It is for the first time that the volume yield of lodgepole pine was determined in 20- to 26-year-old experimental plantations in the Leningrad region of Russia.

\section{KEY WORDS}

introduction, lodgepole pine, forest plantations, growth, standing crop

\section{INTRODUCTION}

In Russia, forest productivity has been gradually declining in recent years in the areas where it would be profitable to grow plantations as economic activities. This being so, intensification of forest cultivation has become of specific relevance; the challenge is to provide high volume yield within the shortest possible time.

In this regard, particular attention should be given to the assortment of plantation species, the biologi- cal properties of which shall conform to the habitat (Markova and Zhigunov 1999). With this aim in view, it is possible to introduce fast-growing exotic species of various origins.

Although the potentials of introduction have not been used in Russia in full measure so far, a large number of practical experiments of Russian researchers have proved that using productive exotic species can provide a 1.5 - to 2 -fold increase in wood production and reduce the rotation period (Botenkov 1997). This was 
confirmed by researchers from Scandinavian and Baltic countries (Lapin 1979; Elfving and Norgen 1993).

A great contribution to the introduction of exotic species in the Russian north-western taiga forests was made by Girgidov (1955) who pointed out that if properly managed, the introduced species could be added to the assortment of valuable and fast-growing local species. The whole list of species that are capable of competing with local forest tree species and thus show promise for introduction was compiled by Bolotov (1992).

The problems of introduction have been the subject matter of detailed studies both in Russia (Drozdov and Yangutov 1984; Demidova et al. 2016; Gutiy and Fedorkov 2016) and abroad (Sutton et al. 2002; Johnstone and Chapin 2003; Saenz-Romero and Guries 2002).

Lodgepole pine has always attracted considerable interest of researchers in many countries. It was the first species introduced commercially in Sweden in the early 1970s. Thirty years later, there were about 600,000 ha of plantations of lodgepole pine, whereas the annual limit for establishing plantations (specified in 1994) was 14,000 ha (Ericsson 1994).

At present, many countries have their lodgepole pine plantations: Ireland, Iceland, the United Kingdom, Denmark, Norway, Finland, Sweden, New Zealand and others (Elfving et al. 2001). Alongside with Sweden, Great Britain has the largest areas of such plantations $(>200,000$ ha by the end of the 20 th century).

One of the first lodgepole pine plots in Russia was established at the beginning of the 20th century in the Vladimir region; at the present time, it is in a good state and shows high growth rates (Shirnin 1992). In Karelia, there is also a large old lodgepole pine plot established in the 1930s not far from Sortavala (Raevskii 2015).

The lodgepole pine plantations in the Leningrad region of Russia offer us a unique possibility to estimate their productivity in the local conditions.

In the following sections, we consider the results of the research on estimating the growth of 20- to 26-yearold lodgepole pine plantations in the Leningrad region of Russia.

\section{MATERIAL AND MEthods}

We examined four forest plantations with five experimental plots, which were established with 2-year-old seedlings of lodgepole pine, Scots pine and Norway spruce grown in Sota hard-plastic containers with 0.4-1 cells. The seedlings were grown in greenhouses during the first vegetation period and in the outdoor field during the second vegetation period.

The 2-year-old seedlings were planted with cylindrical shovels.

Plot 1 is located near Druzhnaya Gorka 59 $16^{\prime} 28^{\prime \prime} \mathrm{N}$ 3009'32"E, Russia.

Features: fresh cutover land; forest type (soil cover) - spiraea; plantation age - 20 years; tillage - PSh1 plough to make elevated soil layers of $20-25 \mathrm{~cm}$ in height and mix the mineral and humus layers; planting step $-0.5 \mathrm{~m}$.

Plot 2 is located near Druzhnaya Gorka $59^{\circ} 16^{\prime} 52^{\prime \prime} \mathrm{N}$ 3009'51'E, Russia.

Features: fresh cutover land; forest type (soil cover) - spiraea; plantation age - 20 years; tillage - PSh1 plough to make elevated soil layers of $20-25 \mathrm{~cm}$ in height and mix the mineral and humus layers; planting step $-0.7 \mathrm{~m}$.

Plot 3 is located near Begunitsy $59^{\circ} 34^{\prime} 15^{\prime \prime} \mathrm{N}$ $29^{\circ} 15^{\prime} 41^{\prime \prime}$, Russia.

Features: fresh cutover land; plantation age - 23 years; soils - sod-podzolic light loamy slightly, fresh, on calcareous sediments of the Izhora plateau, well-drained, 15-20 cm humus horizon; humus content - 3.7-5.0\%; $\mathrm{pH}-4.5$; content of phosphorus and potassium in soil - low; tillage - PSh-1 plough to make elevated soil layers of $20-25 \mathrm{~cm}$ in height and mix the mineral and humus layers; planting method - the next but one seat (next nearest).

Plot 4 has the characteristics similar to that of plot 3 , but the planting material were seedlings of Norway spruce and Scots pine and the planting method was the next but one seat (next nearest).

Plot 5 is located near Kurovitsy $59^{\circ} 21^{\prime} 18^{\prime \prime} \mathrm{N}$ $30^{\circ} 09^{\prime} 30^{\prime \prime} \mathrm{E}$, Russia.

Features: old-arable land; plantation age -26 years; relief - flat; forest type (soil cover) - sorrel; soils - sod podzolic loamy; tillage - PKN-600 plough to make elevated layers of $30-40 \mathrm{~cm}$ in height; planting step $-0.7 \mathrm{~m}$; thickness $-3,300$ seedlings/ha. 
Table 1. Characteristics of taxation indicators of forest plantations

\begin{tabular}{|c|c|c|c|c|c|c|c|c|}
\hline \multirow[b]{2}{*}{ Variant } & \multirow[b]{2}{*}{ Plot } & \multirow{2}{*}{$\begin{array}{c}\text { Age } \\
\text { [years] }\end{array}$} & \multicolumn{2}{|c|}{ Growth parameters } & \multirow{2}{*}{$\begin{array}{c}\text { Survival } \\
{[\%]}\end{array}$} & \multirow{2}{*}{$\begin{array}{l}\text { Current density } \\
\text { [trees/ha] }\end{array}$} & \multirow{2}{*}{$\begin{array}{c}\text { Volume } \\
\text { yield } \\
{\left[\mathrm{m}^{3} / \mathrm{ha}\right]}\end{array}$} & \multirow{2}{*}{$\begin{array}{c}\text { Annual increment } \\
{\left[\mathrm{m}^{3} / \mathrm{ha} / \text { year }\right]}\end{array}$} \\
\hline & & & $\begin{array}{l}\mathrm{DBH} \\
{[\mathrm{cm}]}\end{array}$ & $\begin{array}{c}\mathrm{H}_{\text {graph }} \\
{[\mathrm{m}]}\end{array}$ & & & & \\
\hline \multirow{2}{*}{ Pinus contorta } & 1 & \multirow{2}{*}{20} & $10.7 \pm 0.20$ & 9.9 & 60 & 2,070 & 92.2 & 4.6 \\
\hline & 2 & & $11.2 \pm 0.14$ & 8.9 & 54 & 1,830 & 89.0 & 4.5 \\
\hline $\begin{array}{l}\text { P. contorta } \\
\text { Picea abies }\end{array}$ & 3 & \multirow{2}{*}{23} & $\begin{array}{r}15.5 \pm 0.37 \\
7.2 \pm 0.33\end{array}$ & $\begin{array}{r}13.3 \\
8.7\end{array}$ & $\begin{array}{l}83 \\
97\end{array}$ & $\begin{array}{l}1,400 \\
1,700\end{array}$ & $\begin{array}{r}181.0 \\
34.0\end{array}$ & $\begin{array}{l}7.9 \\
1.5\end{array}$ \\
\hline $\begin{array}{l}\text { Pinus sylvestris } \\
\text { P. abies }\end{array}$ & 4 & & $\begin{array}{r}14.2 \pm 0.33 \\
9.0 \pm 0.33\end{array}$ & $\begin{array}{l}12.4 \\
10.2\end{array}$ & $\begin{array}{l}85 \\
99\end{array}$ & $\begin{array}{l}1,270 \\
1,480\end{array}$ & $\begin{array}{r}125.7 \\
52.1\end{array}$ & $\begin{array}{l}5.5 \\
2.3\end{array}$ \\
\hline P. contorta & \multirow{2}{*}{5} & \multirow{2}{*}{26} & $15.6 \pm 0.52$ & 13.8 & 37 & 1,220 & 158.6 & 6.1 \\
\hline P. sylvestris & & & $16.0 \pm 0.43$ & 13.9 & 44 & 1,440 & 199.7 & 7.7 \\
\hline
\end{tabular}

The seeds were collected from 5 plus-tree lodgepole pines in Canada. A similar plot planted with Scots pine of local origin serves as control.

In 2014, we measured the plants' heights (from 10 to 60 plants depending on the variants) and diameters at a height (DBH) of $1.3 \mathrm{~m}$ above the root collar. We checked the plants for survival in the plots by counting the remaining viable plants. Subsequently, the measurements of the plants' heights were used to construct the graphs describing the growth rates most accurately, and the equations to calculate the average heights of the plants $\left(H_{\text {graph }}\right)$ were derived. On the basis of these data, we calculated the volume yields and annual increment of plants (diameter and height). In our calculations, we used the same coefficients for lodgepole pine and Scots pine (Moiseev 1971). Statistical analysis was performed using MS Excel 2007 and Statistica 8.0 (Zhigunov et al. 2002). We analysed the following indicators: average height and diameter, their average error, and standard deviation $(\sigma)$. To determine the validity of differences in diameter between the variants, we compared two independent samples based on Student's $t$-test.

\section{Results}

Linear and volumetric characteristics of the lodgepole pine plantations and their comparison with Norway spruce and Scots pine plantations are presented in Table 1. The measurements have shown that lodgepole pine exceeded Norway spruce (Tab. 2) by a factor of $1.7-2.0$ by DBH and by a factor of $1.3-1.5$ by $H_{\text {graph }}$. However, the differences in these parameters between lodgepole pine and Scots pine cannot be considered as valid.

Table 2. Comparison of DBH increment of two independent samples by Student's t-test

\begin{tabular}{|l|l|c|r|r|}
\hline \multicolumn{2}{|c|}{ Plot/variant } & $\mathrm{df}$ & $\mathrm{t}$-Value & $\mathrm{p}$-Value \\
\hline 5/Pinus contorta & 5/Pinus sylvestris & 117 & 0.463 & 0.644 \\
\hline 4/P. contorta & 3, 4/Picea abies & 290 & 17.245 & $<0.00^{* *}$ \\
\hline 4/P. sylvestris & 3/P. contorta & 166 & 2.529 & $0.012^{*}$ \\
\hline 4/P. contorta & 5/P. contorta & 133 & 0.215 & 0.496 \\
\hline
\end{tabular}

t-Value and the significance level were calculated using Student's t-test for independent samples $\left({ }^{*} \mathrm{p}<0.05 ;{ }^{* *} \mathrm{p}<0.001\right)$.

Table 3. Differentiation of trees by DBH increment

\begin{tabular}{|c|c|c|c|c|c|}
\hline \multirow[t]{2}{*}{ Variant } & \multirow{2}{*}{$\frac{\overrightarrow{0}}{a}$} & \multirow{2}{*}{ 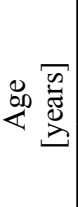 } & \multirow{2}{*}{$\begin{array}{l}\mathrm{DBH} \pm \sigma \\
{[\mathrm{cm}]}\end{array}$} & \multicolumn{2}{|c|}{$\begin{array}{c}\text { Tree } \\
\text { differentiation* } \\
{[\%]}\end{array}$} \\
\hline & & & & average & $\begin{array}{c}\text { fast } \\
\text { growing }\end{array}$ \\
\hline \multirow{2}{*}{ Pinus contorta } & 1 & \multirow{2}{*}{20} & $10.7 \pm 3.07$ & 67 & 18 \\
\hline & 2 & & $11.2 \pm 2.59$ & 67 & 18 \\
\hline $\begin{array}{l}\text { P. contorta } \\
\text { Picea abies }\end{array}$ & 3 & \multirow{2}{*}{23} & $\begin{array}{r}15.5 \pm 3.64 \\
7.2 \pm 3.49\end{array}$ & $\begin{array}{l}72 \\
71\end{array}$ & $\begin{array}{l}13 \\
16\end{array}$ \\
\hline $\begin{array}{l}\text { Pinus sylvestris } \\
\text { P. abies }\end{array}$ & 4 & & $\begin{array}{r}14.2 \pm 2.85 \\
9.0 \pm 3.09\end{array}$ & $\begin{array}{l}67 \\
73\end{array}$ & $\begin{array}{l}15 \\
14\end{array}$ \\
\hline P. contorta & \multirow{2}{*}{5} & \multirow{2}{*}{26} & $15.6 \pm 3.30$ & 65 & 18 \\
\hline P. sylvestris & & & $16.0 \pm 3.82$ & 68 & 18 \\
\hline
\end{tabular}

* Differentiation of trees by growth rates: average - within $\mathrm{DBH} \pm \sigma$; fast growing - from $\mathrm{DBH}+\sigma$ to $\mathrm{DBH}+2 \sigma$.

The highest growth rates amongst the variants with lodgepole pine were observed in plot 4 . Despite the 
younger age of the plants in this plot, the linear parameters $\left(\mathrm{DBH}=15.5 \mathrm{~cm} ; H_{\text {graph }}=13.3 \mathrm{~m}\right)$ in this variant were slightly different from those in the experimental plot $5\left(\mathrm{DBH}=15.6 \mathrm{~cm} ; H_{\text {graph }}=13.8 \mathrm{~m}\right)$. Note that the annual increment was even a bit higher: $7.9 \mathrm{~m}^{3} / \mathrm{ha} /$ year.

Table 3 shows the data on detection of fast-growing plants. One can see that in three of the four plots, fastgrowing lodgepole pine accounts for $18 \%$. Fast-growing Norway spruce accounts for $14-16 \%$ and Scots pine accounts for $15-18 \%$.

\section{Discussion}

The countries of northern Europe show considerable practical interest in lodgepole pine because it grows faster in comparison with not only local forest tree species but also lodgepole pine in its natural habitat (Drozdov and Drozdov 2003). Besides, lodgepole pine wood is valuable raw material for producing pulp both by sulphite and sulphate processes (Drozdov 2008).

This species is promising for cultivation in the Leningrad region of Russia (Markova and Zhigunov 1999). The positive results of lodgepole pine plantations in the Arkhangelsk region are considered by Feklistov (2006). Successful adaptation of this exotic species in the Republic of Karelia was described by Raevskvii (2015) and Mordas' and Raevskvii (1992) and that in the Republic of Komi was described by Fedorkov and Turkin (2010).

There is no agreement amongst the researchers involved in the study of this species regarding the longterm prospects of this species in Russia. Some scientists doubt that this exotic species has great potential for Russia (Shirnin 1999; Shkutko 1970; Gursky 1957). But the majority of researchers insist that lodgepole pine has good prospects for Russia because it has shown itself to good advantage as compared with the local forestforming species (Girgidov 1952, 1955; Raevskii 2015).

Experimental work on plantation cultivation of this exotic species has been conducted since 1982 in the subzones of middle taiga (Karelia) and southern taiga (Leningrad and Novgorod regions). On the basis of these experiments, it has been concluded that at the juvenile stage, lodgepole pine resembles Scots pine in exterior appearance and is similar to it in phenological rhythm. The germination capacity of lodgepole pine seeds from Canada was $73 \%$ and those from Karelian reproduc- tion was $47 \%$. All Canadian provenances $(53-63 \mathrm{~N})$ of lodgepole pine grow well. No relation between the biometric parameters of the planting material and the geographical origin of the seeds has been revealed. Agricultural methods used for growing Scots pine seedlings satisfy the biological requirements for lodgepole pine as well. At the same time, lodgepole pine significantly overtakes Scots pine already in a year after planting; and later, at the age of 3 , the differences remain considerable. The exotic species has a significant advantage: earlier vegetation (by 4 or 5 days); about a month longer period of growth and development of the photosynthetic apparatus; secondary increment in July and August; the total height growth period is twice as long as that of Scots pine (Markova and Zhigunov 1999).

Although the biomechanical resistance to snow and wind loads of lodgepole pine is lower than that of Scots pine, these problems cannot be considered critical. They may be solved by applying better silvicultural and breeding technologies (Raevskii 2015).

Lodgepole pine has a broadest ecological range; it combines a number of valuable biological, anatomical and economic properties such as frost-resistance, comparative tolerance to the lack of heat and soil fertility, resistance to snow blight and the capability of accumulating phytomass within a short period.

Lodgepole pine wood grain has a length of $2.3 \mathrm{~mm}$. The wood is easy to cook (pulp yield is up to $40-50 \%$ ) and to bleach. But unbleached pulp looks good; it has thin stringiness and high strength; it is suitable for the production of newsprint (Raevskii 1997). It also has low content of tar in wood, which brings it closer to Norway spruce (Kutsevalov 1977).

Comparison of lodgepole pine growth in plots 1 and 2 with that of Scots pine grown under similar conditions (Markova et al. 2008) has shown that, at the same age, Scots pine is not much higher than lodgepole pine. According to the authors, Scots pine had the following parameters: $\mathrm{DBH}=13.5 \mathrm{~cm}$ and height $=9.2 \mathrm{~m}$, whereas the Scots pine parameters were $20 \%$ lower by DBH $(10.7-11.2 \mathrm{~cm})$ and were the same by height $(8.9-9.9 \mathrm{~m})$.

According to Raevskii (2015), 24-year-old lodgepole pine plantations in Karelia had a DBH of $14.0 \mathrm{~cm}$ and a height of $11.5 \mathrm{~m}$, which is $10-15 \%$ less than the parameters observed in similar plantations in the Leningrad region $(\mathrm{DBH}=15.5 \mathrm{~cm}$; height $=13.3 \mathrm{~m})$. The lodgepole pine plot established by Girgidov in the Len- 
ingrad region (Girgidov 1952) had even a lower volume yield at the age of $25: \mathrm{DBH}=12.5 \mathrm{~cm}$, height $=11.2 \mathrm{~m}$ and volume yield $=41 \mathrm{~m}^{3} / \mathrm{ha}$. Comparison with the Scots pine plantation $(\mathrm{DBH}=12.1 \mathrm{~cm}$; height $=10.6 \mathrm{~m})$ under the same conditions in the same area favours the lodgepole pine plantation. The latter surpassed Scots pine, although not significant, about 3-5\% in linear parameters; as for the volume yield, the difference was about $50 \%$.

\section{Conclusions}

The following conclusions have been made from the analysis of the researches on lodgepole pine plantations in the southern part of the Leningrad region:

- lodgepole pine has adapted successfully to local conditions; lodgepole pines in these plantations bear cones every year;

- no significant damage from insect pests and diseases in lodgepole pine plantations have been recorded;

- survival of lodgepole pine on different plots varies from $37 \%$ to $83 \%$, but such figures are similar to the survival of local species;

- in the mixed plantations of lodgepole pine and Norway spruce, lodgepole pine will be suppressing Norway spruce because of the rapid growth during the first years of life;

- it is for the first time in the southern part of the Leningrad region of Russia that the volumetric characteristics were obtained for introduced lodgepole pine. At the age of 25 , the volume yield was $180 \mathrm{~m}^{3} / \mathrm{ha}$ and the annual volume yield increment was $7.2 \mathrm{~m}^{3} /$ ha.

\section{References}

Alekseev, V.M. 2009. Silvicultural tests of perspective introduced species in the territory of Novgorod region (in Russian). PhD Dissertation, Saint Petersburg.

Botenkov, V.P., Panova, V.E. 1997. Introduction of highly productive conifer species in Siberia (in Russian). Lesnoe Khozyaistvo, 5, 44.

Girgidov, D.Ya. 1955. Introduction of arboreal species in the North-West part of the USSR (in Russian). Goslesbumizdat, Moscow-Leningrad.
Girgidov, D.Ya. 1952. The lodgepole pine and the red oak in the North-West regions of the USSR (in Russian). Lesnoe Khozyaistvo, 7, 8-13.

Gurskii, A.V. 1957. The main results of the woody plant introduction in the USSR (in Russian). MoscowLeningrad: AN SSSR.

Gutiy, L.N., Fedorkov, A.L. 2016 Experimental plantations of lodgepole pine in the Syktyvkar forestry in the Komi republic (in Russian). Lesnoj Zhurnal, 1, 48-54.

Demidova, N.A. 2016. Growth and development of the lodgepole pine (Pinus contorta Loud. var. latifolia S. Wats) in a northern boreal forest (in Russian). Proceedings of the Saint-Petersburg Forestry Research Institute, 2, 45-59.

Drozdov, I.I., Drozdov, Yu.I. 2003. Forest introduction: Textbook (in Russian). M.: MGUL.

Drozdov, Yu.I. 2008. Lodgepole pine (Pinus contorta) on test plantations of MSFU (in Russian). Lesnoj Vestnik, 1, 188-192.

Elfving, B., Ericsson, T., Rosvall, O. 2001. The introduction of lodgepole pine for wood production in Sweden - a review. Forest Ecology and Management, 141, 15-29.

Elfving, B., Norgren, O. 1993. Volume yield superiority of lodgepole pine compared to Scots pine in Sweden. Pinus contorta from untamed forests to domesticated crop: Proceedings of the IUFRO Meeting and Frans Kempe Symposium 1992, on Pinus contorta provenances and breeding (ed.: D. Lindgren). Department of Forest Genetics and Plant Physiology, Swedish University of Agricultural Science, Umea. Report 11, 69-80.

Ericsson, T. 1994. Lodgepole pine (Pinus contorta var. latifolia) breeding in Sweden - results and prospects based on early evaluations. Dissertation Sweden University of Agricultural Sciences, Umea.

Fedorkov, A.L., Turkin, A.A. 2010. Test of shore pine in the Republic of Komi (in Russian). Lesovedenie, $1,70-74$.

Feklistov, P.A., Biryukov, S.Yu. 2006. Seasonal growth of shore pine in Northern taiga subzone (in Russian). Lesnoj Zhurnal, 6, 24-29.

Johnstone, J.F., Chapin, F.S. 2003. Non-equilibrium succession dynamics indicate continued northern migration of lodgepole pine. Global Change Biology, 9 (10), 1401-1409. 
Kutsevalov, M.A. 1977. Forest cultures of lodgepole pine in the European part of the USSR (in Russian). PhD Dissertation, Leningrad.

Lapin, P.I., Kaluckij, K.G., Kaluckaja, O.N. 1979. Introduction of forest species (in Russian). Lesnaja Promyslennost, Moscow.

Markova, I.A., Zhigunov, A.V. 1999. Silvicultural tests of perspective introduced species in the NorthWest part of Russia (in Russian). Izv. SPbGLTA, Vol. 165, 20-28.

Methodical recommendations on the study of the forest plantations with introduced species (in Russian). 1984. Vsesoiuz. akad. s.-kh. nauk im. V.A. Lenina, Moscow.

Moiseev, V.S. 1971. Forest valuation of young forest: Textbook (in Russian). Leningrad.

Raevskii, B.V. 1997. Growth and productivity of the lodgepole pine in the early stages of their ontogenesis (in Russian). Lesnoe Khozyaistvo, 5, 45-47.

Raevskii, B.V. 2015. Selection and seed growing of the Scots pine (Pinus sylvestris L.) and the lodgepole pine (Pinus contorta Dougl. ex Loud. var. latifo- lia Engelm) in the North-West part of the Russian taiga zone (in Russian). DCs Dissertation, Petrozavodsk.

Saenz-Romero, C., Guries, R.P. 2002. Landscape genetic structure of Pinus banksiana: seedling traits. Silvae Genetica, 1, 26-35.

Shirnin, V.K. 1999. Selection for wood quality (by the example of English oak and other species in zernozem soils of Central Russia) (in Russian). PhD dissertation, Voronezh.

Shkutko, N.V. 1970. Conifer exotic species and their significance for economy (in Russian). Nauka i Technika, Minsk.

Sutton, A., Staniforth, R.J., Tardif, J. 2002. Reproductive ecology and allometry of red pine (Pinus resinosa) at the northwestern limit of its distribution range in Manitoba, Canada. Canadian Journal of Botany, 80 (5), 482-493.

Zhigunov, A.V., Markova, I.A., Bondarenko, A.S. 2002. Statistical processing of the research materials on forest plantations: Training manual. SPbGLTA, SPbNIILKh, Saint Petersburg. 